Uludag Univ. J. Fac. Vet. Med.

32 (2013), 2: 7-10

\title{
Kıvırcık Irkı Koyunlara Ait Bazı Biyokimyasal Değerlerin Belirlenmesi Üzerine Bir Araştırma*
}

Duygu UDUM ${ }^{1}$

\author{
Hakan ÜSTÜNER ${ }^{2}$ \\ Ender $\mathrm{UZABACI}^{3}$
}

Deniz BELENLI ${ }^{1}$

Geliş Tarihi: 11.02.2014

Kabul Tarihi: 26.03.2014

Özet: Bu çalışmanın amacı Kıvırcık ırkı koyunlara ait kan örneklerinde bazı biyokimyasal parametrelerin belirlenmesidir. Araştırma, Manisa ili ilçelerinde yetiştirilen 5 farklı çiftlikten oluşan, 1-6 yaş aralığında, klinik olarak sağlıklı, 30 adet Kıvırcık ırkı koyunlarında yapıldı. Bu hayvanlara ait plazma ve serum örneklerinde, total kolesterol, total protein, trigliserit, fosfolipit, kalsiyum, inorganik fosfor ve glikoz, ticari spektrofotometrik kitler kullanılarak spektrofotometre yardımıyla belirlendi. Kıvırcık ırkı koyunlar arasında çiftliklere göre istatistiksel farkın anlamlı olmadığı saptandı $(\mathrm{p}<0.05)$. Bu araştırma bu ırk ile yapılacak olan diğer çalışmalar için temel teşkil edecek niteliktedir.

Anahtar Kelimeler: Kıvırcık, biyokimyasal değerler, koyun.

\section{Some Serum Biochemistry Values Related to Kıvırcık Ewes in Manisa Province*}

\begin{abstract}
The present study aimed to determine by measuring the levels of several biochemical variables in Kivircik ewes. This study was carried out on 30 Kivircik ewes, 1-6 year old, which were all clinically healty in five different farms from the Manisa province. Total cholesterol, total protein, triglyceride, phospholipids, calcium, inorganic phosphorus and glucose were measured using commercial spectrophotometric kits by spectrophotometer. It's determined that there wasn't diffrence between Kivircik ewes statistically ( $p>0.05)$. The purpose of this study will be beneficial for other studies in this race.
\end{abstract}

Key Words: Kivircık, biochemical values, ewes.

\footnotetext{
$\mathrm{Bu}$ araştırma; Halk elinde ülkesel küçükbaş hayvan ıslahı projesi kapsamında, "Kıvırcık Irkı Koyunların Manisa İlinde Halk Elinde Islah Projesi (45 KIV01)" kapsamında TAGEM tarafından desteklenmiştir.

1 Uludağ Üniversitesi Veteriner Fakültesi Biyokimya Anabilim Dalı, duygudum@uludag.edu.tr

2 Uludağ Üniversitesi Veteriner Fakültesi Zootekni Anabilim Dalı

3 Uludağ Üniversitesi Veteriner Fakültesi Biyoistatistik Anabilim Dalı
} 


\section{Giriş}

Türkiye'nin coğrafik şartları çiftlik hayvanları içerisinde daha çok koyun yetiştirmeye elverişlidir ${ }^{7}$. Koyunculuk birçok üretim yönüne sahip bir yetiștiricilik şeklidir. Koyunlardan elde edilen verimler 1 rk, yetiştirme yönü ve pazar talebine göre farklılık göstermektedir. Kıvırcık koyunu Marmara ve Ege bölgelerinde yetiştirilen bir ırkımızdır. Kuyruğu yağsız ırklardan Kıvırcık koyunu ülkemiz dışında Bulgaristan ve Yunanistan'da yetiştirilen bir irktır. Kıvırcık koyunu ülkemizdeki diğer rrklar gibi ekstansif koşullarda mera, otlak ve anızlara bağlı olarak yetiştirilmekte y1l boyunca çok kısa bir süre konsantre yem verilmektedir.

Koyunlarda süt ve et verimi; 1rk, bakımbeslenme, kondüsyon, doğum tipi, yaş, ${ }^{6,17}$ canlı ağırlık ile meranın kalitesi gibi birçok faktörden etkillenir $^{3,19}$. Kıvırcık 1rk1 et kalitesi yönünden Türkiye koyun irkları arasında diğer 1rklardan ayrılır. Yağın kas lifleri arasında dağılımının iyi olması, Kıvırcık ırkını diğer 1rklardan üstün k1lar. Süt kesiminden sonra besiye alınan kuzular ülke koşullarında diğer ırklar gibi erken dönemde kesim olgunluğuna ulaşırlar. ${ }^{1}$

Koyunlarda gerek hastalık teşhisi gerekse verim düzeylerinin korunması ve artırılmasında serum biyokimyasal parametrelerden yararlanılmaktadır. Klinik biyokimya laboratuvar metodlarıyla elde edilen sonuçlar, hastalığın erken teşhisi, etiyolojisi, patogenezi, seyri ile uygulanan bir tedavinin kontrolu hakkında hekime bilgiler verir. ${ }^{4} \mathrm{Bu}$ nedenle diğer çiftlik hayvanlarında olduğu gibi koyunculuk içinde bu değerlerin bilinmesi yararlı olacaktır. Coğrafi farklılıklara göre irkların yetiştirildikleri bölgeye özgü referans değerlerinin ortaya konulması gereklidir. Yapılan literatür taramasında Kıvırcık ırkına özgü serum biyokimyasal değerlere rastlanamamıştır. Bu çalışma ile birlikte Kıvırcık koyunların bazı biyokimyasal parametreleri belirlenerek bu irk ile yapılacak olan diğer çalışmalar için yararlı olacaktır.

\section{Materyal ve Metot}

Araştırmanın materyalini Manisa ili ilçelerine ait 5 farklı koyun sürüsünde, 1 ile 6 yaş aralığındaki sağlıklı Kıvırcık ırk1 koyunlardan alınan 30 adet kan örneği oluşturdu. Hayvanlar ekstansif koşullarda meraya dayalı olarak beslenmektedirler. Hayvanlar gün içerisinde 12 saat aç bırakıldıktan sonra vena jugularis'inden 10 ml'lik heparin'li, EDTA'lı ve serumluk tüplere kan örnekleri alınmıştır. Soğuk zincir prosedürüne uygun olarak labotaruvara taşınan kanlar, 15 dakika süresince 3000 rpm'de santrifüj edilmiştir. Kanlar dondurulmadan biyokimyasal parametreler açısından analizleri yapılmıştır. Analizler, Uludağ Üniversitesi, Veteriner Fakültesi, Biyokimya Anabilim Dalı Laboratuarı'nda yapılmıştır. Plazma ve serum örneklerinde, total kolesterol (Fluitest, Cholesterol), total protein (Biolabo, Total Protein, Biuret method), trigliserit (Biolabo, triglycerides GPO method), fosfolipit (Biolabo, phospholipids), kalsiyum (Teco Diagnostics, calcium, colorimetric method), inorganik fosfor (Teco Diagnostics, inorganic phosphorus color method) ve glikoz (Teco Diagnostic, Glucose/ GOD colorimetric kit), ticari spektrofotometrik kitler kullanılarak spektrofotometre yardımıyla (Shimadzu UV 1601) belirlenmiştir.

Veriler, SPSS 20.0 paket programında değerlendirilmiştir. Kruskal-Wallis ve MannWhitney U testi yardımıyla gruplar arasındaki farklılıklar belirlenmiştir.

\section{Bulgular}

Kıvırc1k 1rkı koyunların bazı serum biyokimyasal değerleri tablo 1'de sunulmuştur.

Tablo 1'de görüldüğü gibi gruplar arasında kan serumu biyokimyasal değerleri bakımından Kivircık 1rk1 koyunlar arasında istatistiksel farkın anlamlı olmadığı saptandı $(\mathrm{p}>0.05)$.

\section{Tartışma ve Sonuç}

Araştırmada kliniklerde sıkça başvurulan ve daha çok klinik olarak bir bozukluğun göstergesi olan temel biyokimyasal kan parametreleri dikkate alınmıştır. 
Tablo 1: Kıvırcık ırkı koyunların gruplara göre bazı serum biyokimyasal değerleri. Table 1: Some serum biochemistry values of kıvırcık ewes in different groups

\begin{tabular}{|l|c|c|c|c|c|c|c|}
\hline & $\begin{array}{c}\text { Grup 1 } \\
(\mathrm{n}=6)\end{array}$ & $\begin{array}{c}\text { Grup 2 } \\
(\mathrm{n}=6)\end{array}$ & $\begin{array}{c}\text { Grup 3 } \\
(\mathrm{n}=6)\end{array}$ & $\begin{array}{c}\text { Grup 4 } \\
(\mathrm{n}=6)\end{array}$ & $\begin{array}{c}\text { Grup 5 } \\
(\mathrm{n}=6)\end{array}$ & $\begin{array}{c}\text { Toplam } \\
(\mathrm{n}=30)\end{array}$ & Önem \\
\hline Glikoz (mg/dl) & $60.59 \pm 8.10$ & $54.78 \pm 3.17$ & $49.80 \pm 3.74$ & $45.47 \pm 8.18$ & $43.45 \pm 4.08$ & $50.82 \pm 2.70$ & $\mathrm{~ns}$ \\
\hline Total protein(g/dl) & $6.18 \pm 1.64$ & $6.34 \pm 1.35$ & $6.43 \pm 1.03$ & $4.79 \pm 0.73$ & $7.17 \pm 1.09$ & $6.18 \pm 0.52$ & $\mathrm{~ns}$ \\
\hline Trigliserit (mg/dl) & $33.22 \pm 1.96$ & $41.61 \pm 11.0$ & $14.63 \pm 5.43$ & $29.98 \pm 6.93$ & $28.56 \pm 2.50$ & $29.60 \pm 3.13$ & $\mathrm{~ns}$ \\
\hline $\begin{array}{l}\text { T.Kolesterol } \\
(\mathrm{mg} / \mathrm{dl})\end{array}$ & $61.16 \pm 7.91$ & $71.33 \pm 15.0$ & $38.34 \pm 5.61$ & $48.79 \pm 3.52$ & $61.24 \pm 5.13$ & $56.17 \pm 4.10$ & $\mathrm{~ns}$ \\
\hline Fosfolipit (mg/dl) & $118.75 \pm 8.7$ & $136.10 \pm 30.7$ & $94.57 \pm 23.5$ & $81.56 \pm 16.4$ & $78.34 \pm 9.5$ & $101.86 \pm 9.1$ & $\mathrm{~ns}$ \\
\hline Kalsiyum (mg/dl) & $8.22 \pm 0.19$ & $8.33 \pm 0.03$ & $7.54 \pm 0.83$ & $8.13 \pm 0.08$ & $8.15 \pm 0.08$ & $8.07 \pm 0.16$ & $\mathrm{~ns}$ \\
\hline Fosfor (mg/dl) & $2.18 \pm 0.41$ & $3.80 \pm 0.78$ & $4.01 \pm 0.94$ & $3.15 \pm 0.90$ & $3.02 \pm 0.31$ & $3.23 \pm 0.32$ & $\mathrm{~ns}$ \\
\hline
\end{tabular}

ns: $\mathrm{p}<0.05$

Çalıșmada 1 ila 6 yaș arasındaki Kıvırcık 1rkı koyunların en düşük ve en yüksek glikoz değeri $43.45-60.59 \mathrm{mg} / \mathrm{dl}$ arasında bulunmuştur. Schultz ${ }^{21}$, Ruminantlarda kan glikozunun normal olarak $40 \quad-50 \mathrm{mg} / 100 \mathrm{ml}$. olduğunu bildirmektedir. Bostedt ${ }^{8}$ 1-4 yaşlarında Merinos koyunlarında glikoz oksidaz metodu ile yaptığ 1 bir çalışmaya göre gebeliğin başlangıcında kan glikozunun ortalama $62-42 \mathrm{mg} / 100 \mathrm{ml}$. olduğu ve bu değerin gebeliğin 5. ayında \% 30 yükselme gösterdiğini tespit etmiştir. Akkaraman 1rkı koyunlarda 44.56 - $58.00 \mathrm{mg} / \mathrm{dl}$, Merinos 1rk1 koyunlarda $62.76-72.80 \mathrm{mg} / \mathrm{dl}^{5}, 57.0-66.2$ $\mathrm{mg} / \mathrm{dl} .{ }^{15}$ Nispet ve ark. ${ }^{16}$ dişi koyunlarda $40-84$ $\mathrm{mg} / \mathrm{dl}$, erkek koyunlarda 40 - $77 \mathrm{mg} / \mathrm{dl}$ bulmuşlardır. Araştırmada Kıvırcık 1rkı koyunlarda bulunan glikoz değerleri, diğer çalışmalar ile benzerlik göstermekle beraber sürüler arasında istatistiksel bakımdan bir önem bulunmamıştır ( $\mathrm{p}>0.05)$.

Çalışmada Kıvırcık ırkı koyunların serum total protein değerleri $4.79-7.17 \mathrm{~g} / \mathrm{dl}$ arasında bulunmuştur. Nisbet ve ark. ${ }^{16}$ total proteini dişi koyunlarda $6.1-8.6 \mathrm{~g} / \mathrm{dl}$ erkek koyunlarda 6.1 $-8.4 \mathrm{~g} / \mathrm{dl}$, Kurt ve ark. ${ }^{14} 7.7 \pm 0.86 \mathrm{~g} / \mathrm{dl}$ olarak bulurken; Çimen ve ark. ${ }^{10}$, serum total protein değerlerini Akkaraman 1rk1 koyunlarda $6.82 \pm 0.15 \mathrm{~g} / \mathrm{d} 1$, Karayaka 1 rk1 koyunlarda $6.56 \pm 0.16$ g/dl, Kırmızıgül ve ark. ${ }^{13}$, sağlıklı 20 koyunda serum total protein değerlerini $8.66 \pm 0.58 \mathrm{~g} / \mathrm{dl}$ olarak bulmuşlardır ve bulunan tüm serum total protein değerleri çalışmamızda elde ettiğimiz total protein seviyeleri ile benzerlik göstermektedir. Ayrıca gruplar arasında istatistiki açıdan bir önem bulunmamıştır ( $p>0.05)$.

Çalışmada, Kıvırcık ırkı koyunların trigliserit düzeyleri $14.63-41.61 \mathrm{mg} / \mathrm{dl}$ arasında bulunurken toplam kolesterol seviyeleri 38.34 $71.33 \mathrm{mg} / \mathrm{dl}$ arasında tespit edilmiştir. Gündüz ve Mert ${ }^{15}$ Bandırma Koyunculuk ve Araştırma Enstitüsü'nde bulunan Dorset, Lincoln, Hampshire, Siyah Baş Alman ve Border Irkı etçi ko- yunlarda trigliserit düzeylerini $22.3 \pm 3.0-22.7$ $\pm 2.1 \% \mathrm{mg}$ arasında; toplam kolesterol düzeylerini $66.3 \pm 4.3-94.6 \pm 3.5 \% \mathrm{mg}$ arasinda bulmuşlardır. Kurt ve ark. ${ }^{14}$ Adıyaman bölgesinde merada yetiştirilen ve klinik olarak sağlıklı Morkaraman koyunlarda ortalama trigliserit değerini $36.88 \pm 19.41 \mathrm{mg} / \mathrm{dL}$, toplam kolesterol değerini $74.48 \pm 22.33 \mathrm{mg} / \mathrm{dl}$ olarak tespit etmişlerdir.

Erkan ve ark. ${ }^{11}$, yaptıkları çalışmada trigliserit seviyesi klinik olarak sağlıklı grupta $23.92 \pm 1.96 \mathrm{mg} / \mathrm{dl}$ iken florozisli grupta 33,50 $\pm 3,89 \mathrm{mg} / \mathrm{dl}$ ve kolesterol düzeyleri de siras1 ile $55.30 \pm 2.48$ ve $67.81 \pm 2.72 \mathrm{mg} / \mathrm{dl}$ olarak bulmuşlardır. Nispet ve ark. ${ }^{16}$ total kolesterol; Karayaka 1rkı dişi koyunlarda 36 - 78 mg/dl, erkek koyunlarda 32 - 87 mg/dl olarak ölçmüşlerdir. Bulunan bu değerlere göre çalışmamızda grup 3'ün trigliserit ve total kolesterol seviyeleri düşük olarak belirlenmekle birlikte sürüler arasindaki farklılık istatiski olarak anlamlı bulunmamıştır ( $p>0.05)$.

Çalışmamızda serum fosfolipit değerleri $78.34-136.10 \mathrm{mg} / \mathrm{dl}$ arasinda bulunmuştur. Piccione ve ark. ${ }^{20}$, Comisana koyunlarında $88.79-99.70 \mathrm{mg} / \mathrm{dl}$, Kusabek ve ark. ${ }^{12}$ kuzu ve koyunlar fosfolipit değerlerini $55-145 \mathrm{mg} / \mathrm{dl}$ arasında bulmuşlardır.

Kivircik koyunlarda bulunan kalsiyum değerleri $7.54-8.33 \mathrm{mg} / \mathrm{dl}$ arasında tespit edilmiştir. Altıntaş ve ark. ${ }^{4}$, koyunlarda 11.5 - 12.8 $\mathrm{mg} / \mathrm{dl}$. Özyurtlu ve ark. ${ }^{18}$ İvesi koyunlarında serum kalsiyum değerlerini $7.92-8.66 \mathrm{mg} / \mathrm{dl}$, Aksoy ve $\operatorname{ark}^{2}$ İvesi kuzularda $9.47-10.96$ $\mathrm{mg} / \mathrm{dl}$ olarak bulmuşlardır. Tespit edilen değerler literatürlerle uyum içerisindedir.

Fosfor çalışmamızda inorganik fosfor değerleri $2.18-4.01 \mathrm{mg} / \mathrm{dl}$ olarak bulunmuştur. Altıntaş ve ark. ${ }^{4}$, inorganik fosfor değerlerini $4.5-7.5 \mathrm{mg} / \mathrm{dl}$ Özyurtlu ve ark. ${ }^{18}$ İvesi koyunlarında serum fosfor değerlerini 2.56 - 3.27 
$\mathrm{mg} / \mathrm{dl}$ olarak bulmuşlardır. Elde edilen değerler literatürlerle benzerlik göstermektedir.

Bu çalışmada sunulan Manisa ilinde 5 ayr1 çiftlikteki Kıvırcık koyunların bazı serum biyokimyasal değerleri bu hayvanlarla ilgili yapılacak çalışmalara ışık tutacaktır.

\section{Kaynaklar}

1. Akçapınar H., Koyun Yetiştiriciliği, Yenilenmiş 2. Bask1, İsmat Matbaacılık, Ankara.1994, syf 168-169.

2. Aksoy, G., Tekin, Şahin., İbrahim, Çimtay,. Neval, Berrin,. Arserim, Kaya,. 2002. Kuzularda Çinko Oksit Uygulamalarının Bazı Biyokimyasal Parametreler ve Canlı Ağırlık Kazancı Üzerine Etkileri. Turkish Journal of Veterinary Animal Science, 26, 85-90.

3. Al-Saigh, M., Al-Kuzai, A.D., 1991. Possibilities of predicting total milk yield and lamb weaning weihg from partial milk yield and weing of ewes and their lambs at different periods in arabia sheep. A B A., 59 (7), 4787.

4. Altıntaş, A., Fidanc1, U.R., 1993. Evcil hayvanlarda ve insanda kanın biyokimyasal normal değerleri. Ankara Üniv Vet Fak Derg., 40, 173-186.

5. Avcı, G., Küçükkurt, İ., Kontaş, T., Eryavuz, A., Fidan, F., 2013. Farkl1 1rk koyunlarda rasyona çinko ilave edilmesinin plazma leptin, insulin ve tiroid hormon düzeyleri ile bazı biyokimyasal parametreler üzerine etkisi. Ankara Üniv Vet Fak Derg. 60, 1-5.

6. Baş, S., Özsoy, M.K., 1986. Vanlı Y. Koç katımı öncesi farklı sürelerde yemlemenin koyunlarda döl verimine, kuzularda büyüme ve yaşama gücüne etkileri. Doğa Tr Vet Hay Derg. 10 (3), 221 230.

7. Başpınar, H., 1985. Türkiye'deki başlıca koyun ırklarının yarı-entansif koşullarda döl, süt ve yapağı verim performansları üzerine mukayeseli bir araştırma. İstanbul Üniversitesi, Veteriner Fakültesi Dergisi 11, 43-66.

8. Bostedt, H., 1971. Vergleichende Utersuchungen über die anderungen der Blutglukosenzentration und der Zahl der eosinophile Leukozyten bei Schaf und Schwein intra-und nost artum. Berliner und Müchener Tierarrtl. Wschr. 84, 3-8.

9. Cenesiz, S., Ozcan, A., Kaya, N., Baysu, N., Bay Karabulut, A., 2005. Chronic effects of fluoride in tuj sheep on serum levels of total protein, albumin, uric acid, and nitric oxide and activities of lactate dehydrogenase and leucine aminopeptidase 52 Fluoride 38(1), 52-56.

10. Çimen, M., Karaalp, M., Elmastaş M., 2001. Farklı yerli koyun 1rklarına ait bazı kan paramet- relerinin belirlenmesi üzerine bir araştırma. G.O.Ü. Ziraat Fakültesi Dergisi. 18, 135-136.

11. Erkan, S., Fidanc1, U.R., 2011. Florozisli koyunlarda serum lipid profili. Ankara Üniversitesi Veteriner Fakültesi Dergisi, 58, 149-153.

12. Kubasek, F.0.T., Buttress, N. F., 1976. Plasma lipoproteins of lambs and sheep. by w. m. f. leat, Quarterly Journal of Experimental Physiology. 61, 193-202.

13. Kırmızıül, A.H., Uzlu, E., Çitil, M., Güneş, V., Gökçe, G., 2005. Sağlıklı Koyunlarda Güçlü İyon Farkı ve Uçucu Olmayan Zayıf Asitlerin Toplam Konsantrasyonunun Hesaplanması Kafkas Üniv. Vet. Fak. Derg. 11, 103-106.

14. Kurt, D., Yokuş, B., Çakır, D.Ü., Denli, O., 2008. Investigation Levels of Certain Serum Biochemistry Components and Minerals of Pasturing Akkaraman Sheeps in Adiyaman Province. Dicle Univ Vet Fak Derg. 1, 34-37.

15. Mert, N., Gündüz, H., Akgündüz, V., Akkündüz, M., 2003. Merinos Melezi Koyunlarda Bazı Biyokimyasal Kan Parametreleri ile Verim Arasındaki ilişkiler III- Glikoz, Alkali Fosfataz, Seruloplazmin. Turk J Vet Anim Sci. 27, 583-588.

16. Nispet, C., Yarım, G.F., Çiftçi, G., 2006. Sağlıklı Karayaka 1rkı koyunlara ait bazı serum biyokimyasal değerleri. Ankara Üniv Vet Fak Derg. 53, 57-59.

17. Odabaşığlu, F., 1985. Morkaraman, akkaraman ve ivesi koyunlarının verim özelliklerinin karşılaştırılması (Yarı entansif şartlarda döl verimi, süt verimi ve laktasyon süreleri yönünden karşılaşt1rılması). Elazığ Böl Vet Hek Odası Derg. 1, 1626.

18. Özyurtlu, N., Gürgöze, S.Y., Bademkıran S., Şimşek, A., Çelik, R., 2007. İvesi Koyunlarda Doğum Öncesi ve Sonrası Dönemdeki Bazı Biyokimyasal Parametreler ve Mineral Madde Düzeylerinin Araştırılması F.Ü. Sağ. Bil. Derg. 21, $33-36$.

19. Özcan, H.,1974. Koyunların yaşı, canlı ağırlığı, süt verimleri ile kuzuların doğum ağırlığı ve gelişimi arasındaki ilişkiler. A Ü Elazığ Vet Fak Derg. 1(1), 3-15.

20. Piccione, G., Caola, G., Giannetto, C., Grasso, F., Runzo, S.C., Zumbo, A., Pennisi, P., 2009. Selected biochemical serum parameters in ewes during pregnancy, post-parturition, lactation and dry period. Animal Science Papers and Reports vol. 27(4), 321-330.

21. Schultz, L.H., 1968. Ketozisin dairy cattle J. Dairy Sci., 51, 1130-1140. 